\title{
Bingöl'ün Yaşanabilir Kent Olma Yolunda Fiziki Problemleri ve Öncelikleri Üzerine Bir Değerlendirme
}

DOI: $10.26466 /$ opus.672743

*

\author{
Hüccet Vural* \\ * Dr. Öğr. Üyesi, Bingöl Üniversitesi, Bingöl/Türkiye \\ E-Posta: hvural@bingol.edu.tr \\ ORCID: $\underline{0000-0001-6115-1572}$ \\ Öz
}

Kentlerin gerek nüfus, gerekse kapladığg alan bakımından büyük olması bilimsel ve teknik kurallar çerçevesinde şekillendirilmesini gerekli kılmaktadır. Diğer taraftan, kentler nüfus ve fiziki bakımdan büyüdükçe farkl sorunlarla yüz yüze kalmaktadır. Araştırmada Bingöl kent merkezinin kentleşme sürecini etkileyen temel sorunlarının ve önceliklerinin katılımo yaklaşımla ele alınması amaçlanmıştır. Araştırmada, birincil kaynaklardan veri toplamada en yaygin yöntem olarak bilinen anket tekniği kullanılmıştır. Farklı demografik yapıdan 598 kişi ile yapılan anket çalışmasından elde edilen sonuçlar SPSS program kullanılarak analiz edilmiştir. Anket verilerinin yorumlanmasında betimsel değerlendirmelerin yanında katılımo profili ve eski-yeni kent dokusu değişkenlerine göre anlamlılık testleri kullanılmıştır. Araştırmaya katılan bireylere göre en önemli problemler, mahalle ölç̧ğinde yeşil alan yetersizliği ve çevre kirliliği-çöp sorunu, kent genelinde ise yeşil alan yetersizliği ve otopark sorunudur. Ayrıca katılımcıların çözüme yönelik öncelikleri birinci sırada yeşil alan yetersizliği $(\% 17,8)$, ikinci sırada çevre kirliliği-çöp sorunu $(\% 13,1)$ ve üçüncü strada ise trafik sorunu $(\% 12,4)$ gelmektedir. 16 Sorun alanı ile ilgili yapılan değerlendirmede eski-yeni yerleşim bölgelerinde sonuçların de$\breve{g}$ işmediği belirlenmiştir. Araştırma sonuçları sürdürülebilir ve yaşanabilir bir kent gündeminin zaman geçirilmeden oluşturulmasının gerekliliğini göstermektedir.

Anahtar Kelimeler: Bingöl, kentsel çevre sorunları, planlama sürecine katılım, kent öncelikleri, sürdürülebilir kentleşme 


\title{
An Evaluation on the Physical Problems and Priorities of Bingöl City on the Path of Being Livable City
}

\begin{abstract}
The fact that cities are large both in terms of population and the area it occupies requires them to be shaped within the framework of scientific and technical rules. On the other hand, cities face different problems as they grow in terms of population and physical. In the study, it was aimed to address with participatory approach the main problem and priorities affecting the urbanization process in Bingol's center. The survey technique, which is known as the most common method of collecting data from primary sources, was used in this the study. The results of the survey collected with 598 people from different demographic feature were analyzed by using SPSS software. In addition to the descriptive evaluations, it was used for meaningfulness tests according to participant profile and old-new urban texture variables. According to the individuals who participated in the study, the most important problems were green space deficiency and environmental pollution-garbage problem at the scale of the neighborhood and green space deficiency and parking problem throughout the city. In addition, the priorities of the participants for solutions were lack of green space (17.8\%) firstly, environmental pollution-waste problem (13.1\%) secondly and traffic problem (12.4\%) thirdly. In the evaluation of 16 problem areas, it was determined that the results did not change according to the old-new residential areas. The results of the research indicated that a sustainable and livable city agenda should be established without delay.
\end{abstract}

Keywords: Bingöl, urban environmental problems, participation in planning process, urban priorities, sustainable urbanization 


\section{Giriş}

Kent, kendi sınırları içinde barındırdığı nüfusun günlük hayat akışı içerisinde yer alan aktivitelerin yapıldığı, ihtiyaçların karşılandığı, insanlar arasında sosyal ilişkilerin geliştiği ve onlara rekreasyon, sanat, spor ve kültürel aktivite olanağı sunan mekanlar olarak karşımıza çıkmaktadır. Kent aynı zamanda geçmişten günümüze ortak hatıraların, yaşanmışlıkların, farklılıkların, kültürel izlerin gelecek nesillere bırakıldığı ve uzun tarihsel süreçte şekillenmiş, farklı demografik yapıdan grupların yer aldığı yerleşim alanlarıdır (Aytaç, 2013, s.139). Kent, yönetim yapısı, toplumsal ilişkiler, sosyalkültürel yapısı, olanakları, yaşam biçimleri ve nüfus yoğunluğu bakımından kırsal alanlardan farklılaşmaktadır. Günümüz Dünya nüfusunun büyük çoğunluğunun kentlerde yaşadığı düşünüldüğünde kentlerin önemi daha fazla ortaya çıkmaktadır (Başaran, 2007, s.209). Kentlerin gerek nüfus gerekse de kapladığı alan bakımından büyük olması üzerinde daha özenle durulmasını ve bilimsel, teknik kurallar çerçevesinde şekillendirilmesi gereğini ortaya koymaktadır. Ancak kentler nüfus ve fiziki bakımdan büyüdükçe farklı sorunlarla yüz yüze kalmaktadır.

Kentlerin genişlerken karşılaştığı sorunlar çeşitli kavramların ortaya çıkmasını sağlamıştır. Bu kavramlardan biri "sağlıklı kent" kavramı, diğeri ise "sürdürülebilir kentsel gelişim" kavramıdır. Sağlıklı kent kavramı, yaşanabilir bir kent oluşumu için gerekli tüm unsurları barındıran ve bu yolda ihtiyaç duyulan yapısal değişiklikleri uygulayan kenttir. Kent yaşamının kalitesi aynı zamanda insan sağlığına katkısı nedeniyle önemlidir. Çünkü bireyin yasam kalitesi, huzurlu olması ve mutluluğu kentin yaşam kalitesine olumlu katkı sağlayacaktır (Başaran, 2007, s.208). Sürdürülebilir kent kavramı günümüz kent planlamasında genel bir çerçeve olarak ele alınmakta, planlamayı bir taraftan toplumsal, çevresel ve ekonomik açıdan ele alırken diğer taraftan da ekolojik olarak doğal çevrenin korunmasını ön plana çıkarmaktadır (Kocalar, 2018, s.14). Drakakis-Smith, (1995, s.665) kentsel gelişimin bileşenlerini demografik, sosyal, politik, ekonomik ve çevresel faktörler olarak ele almaktadır. Sürdürülebilir kentsel gelişimin demografik bileşenlerini göç, doğurganlık ve etnik köken, sosyal bileşenlerini temel ihtiyaçlar ve insan hakları, politik bileşenlerini planlamada katılımcılık, demokratik kuruluşlar ve devletin rolü, ekonomik bileşenlerini kentin mali yapısı ve geliri, çevresel bileşenlerini ise yenilenebilir kaynakların sürdürü- 
lebilir kullanımı, yenilenemeyen kısıtlı kaynakların minimum kullanımı ve fiziksel planlamanın uygunluğu oluşturmaktadır. Bunun yanında araştırmacılar sürdürülebilir kentsel gelişim için sosyal adaletin sağlanması gerektiği üzerinde fikir birliğine varmışlardır (Pearsalla and Pierce, 2010, s.570).

Sürdürülebilir kentsel gelişimin fiziki yönü doğal kaynakların korunması, iklim, ekoloji, gibi değişmez öğelerle ilgilenmekteyken, sağlıklı kent ise kent ergonomisi, mekan, aidiyet duygusu, ortak bellek gibi ölçülemeyen olgular üzerine yoğunlaşmaktadır (Oktay, 2007; Sezik, 2018, s.706). Kentlerin sürdürülebilir gelişimi çevre sorunlarına çözüm getirmekle beraber mevcut nüfusun yaşam kalitesinin artırılması ve gelecek nesiller için yaşanabilir mekânların bırakılmasına katkı sunacaktır. Bu nedenle bugün ve gelecek nesiller için insan-doğa-ekonomi üçgeni en sağlıklı biçimde kurulmalıdır (Atıl vd., 2005, s.2016). Özellikle kentsel yeşil alanların kentin yaşam standartlarının iyileştirilmesi, kent estetiğinin sağlanması ve ekolojik servislerin gelişimi üzerine azımsanmayacak katkısı bulunmaktadır (Jim, 2013, s.741).

Türkiye kentlerinin kentleşme sürecini etkileyen ana unsurların başında göç gelmektedir. Kent merkezlerinin sahip olduğu sosyal, ekonomik ve kültürel olanakların kırsal alanlara göre daha cazip olması kent merkezlerine olan göçü artırmıştır. Özellikle 1980'li yıllar Türkiye'nin kentleşme sürecinin doyuma ulaştığı ve nüfus hareketliliğin yüksek oranda yaşandığı yıllardır. 2000'li yıllarda kentlerin fiziki yapısını şekillendiren kentsel dönüşüm veya yenilenme yaklaşımın yaşandığı yıllar olarak karşımıza çıkmaktadır (Yenice, 2012, s.344). Teknolojik gelişmelerle birlikte ise günümüz kent anlayışında bilgi teknolojilerinin kullanıldığ ${ }_{1}$ akıllı kent dönemi yaşanmaktadır. Akıllı kentler, teknolojinin kente entegre edilerek altyapı, enerji, ulaşım, çevre, iletişim, temiz su, gibi temel hizmetlerin bir merkezden ve huzlı bir biçimde halka sunulduğu kentleri ifade etmektedir (Sınmaz, 2013, s.77). Ayrıca akıllı kentlerde halkın entelektüel hayata uyumu, sosyal, sanatsal ve kültürel bakımdan gelişimi hedeflenmektedir.

Modern ya da gelişmiş kentler, planlı büyümenin sağlandığı, altyapı sorunlarının çözüldüğü, ulaşım hizmetlerinin gerek kamu gerekse de özel sektör aracılığ 1 ile çeşitlendirildiği, sağlık alanında önemli ilerlemenin yaşandığı, çevre bilincinin yükseldiği ve insanların boş zamanlarını geçireceği rekreasyon alanlarının bulunduğu kentler olarak görülmektedir (Yüksel ve Yeşil, 2017, s.681). Bunun aksine kente olan nüfus hareketliliğini iyi yönete- 
meyen, fiziki gelişmeyi belli bir plan doğrultusunda yürütemeyen ve kent yönetimi konusunda gerekli kararları zamanında uygulamaya konulamayan kentlerde önemli sorunlar meydana gelmektedir. Bu sorunlar Güven ve Alan $(2018$, s.1883) tarafından kent kökenli sorunlar ve çevresel sorunlar olmak üzere iki grupta açılanmaktadır.

Kent kökenli sorunların temelinde kent nüfusunun beklenmeyen artışı gelmektedir. Kente gelecek nüfusun ihtiyaçlarını giderici çözümlerin üretilememesi sonucu altyapı sorunları, konut yetersizlikleri, çarpık ve düzensiz kentleşme, yeşil alan yetersizlikleri, imar problemleri, yoğun trafik gibi çeşitli sorunlar meydana gelmektedir. Çevresel sorunların temelinde ise insanın ekosistemi bozucu faaliyetleri ve doğal kaynaklardan yararlanırken çevreye verdikleri olumsuzluklardan kaynaklanmaktadır (Güven ve Alan, 2018, s.1884). Çevresel sorunlar toprak, hava, su ve çevre gibi doğal kaynakların plansız ve hatalı kullanımından kaynaklanan kirlenmenin oluşturduğu temel sorunlardır. Sorunun niteliği ve niceliğinin artması sera gazlı ısınma, ormansızlaşma, çölleşme, biyolojik çeşitlilikteki kayıplar gibi küresel ölçekte sorunların meydana gelmesine sebep olmaktadır. Kentsel alanlar antropojenik faaliyetler, endüstriyel faaliyetler, taşıma, ısınma ve soğutma amaçlı yakıt kullanımı gibi kirletici kaynaklardan oluşan kirlenmenin \%90'nından sorumludur. Dolayısıyla kentleşme ile küresel iklim değişikliği arasında bağlantı bulunmaktadır. Nitekim kentsel iklim bilimcileri kentin morfolojisi, binaların yüksekliği, genişliği ve yoğunluğu gibi farklı etkenlerle sıcaklığın $1-3^{\circ} \mathrm{C}$ artabildiğini, kırsal alanlara göre ise $10^{\circ} \mathrm{C}^{\prime}$ ye kadar fazla olabildiğini göstermektedir (Grimmond, 2005, s.83).

Kentlerde gerek kentin fiziki yapısından kaynaklanan sorunlar ve gerekse de insan faaliyetleri sonucu meydana gelen sorunlar kent yaşantısında olumsuz sonuçlar doğurmaktadır. Bu sonuçların başında kentlinin yaşam kalitesinin negatif etkilenmesi gelmektedir. Modern toplumlarda yaşam kalitesi sadece teknolojik ilerlemeler ve gelir artışı gibi maddi zenginliklerden ibaret değildir. Bunun yanında kent ile insan arasında etkileşimin kurulmasını, insanın yaşadığı çevre koşullarının uygun olmasını, sosyal, politik ve çevre sağlığı da dâhil olmak üzere insan sağlığı ve refahını etkileyen tüm unsurların göz önünde bulundurulmasını gerekli kılmaktadır (Pacione, 2003, s.19). Yaşam kalitesinin artırılmasında nihai hedef halkın memnuniyeti ve mutluluğudur. 
Kentsel sürdürülebilirliği teşvik etme ve yaşam kalitesinin artırılmasında diğer bir faktör katılımcllıtır. Kentsel sistemlerin yönetişimine kapsayıı ve katılımcı bir yaklaşımın uzun vadeli sosyal, kültürel, çevresel ve ekonomik sürdürülebilirliklerini sağlamada daha başarılı olacağ edilmektedir. $\mathrm{Bu}$ alandaki birçok bilim insan, yerel çevre politikalarının halk arasında daha yüksek bir uzlaşma ve destek alması ile uzun vadede daha sürdürülebilir ve etkili olacağı vurgulanmaktadır (Bonnes vd., 2007, s.63). Çünkü yaşayan halk kentin bugünü ve geleceğinin planlanması üzerine en doğru ve yansız değerlendirici bir aktördür. Araştırma alanı olarak belirlenen Bingöl ilinin kentsel sorun alanlarını inceleyen az sayıda araştırma (Soylu, 2009; Üstündağ, 2011; Tatlılığlu, 2015) bulunmasına rağmen halkın kentleşme süreci ile ilgili görüş, beklenti ve taleplerini ele alan çalışmaya rastlanılmamıştır.

Araştırmada Bingöl ilinin kentleşme sürecinin ve fiziki çevre ile ilgili temel kentsel problemlerinin katılımcı bakış açısı ile ele alınması ve değerlendirilmesi amaçlanmıştır. Ayrıca araştırmada halkın gerek yaşadığı mahalle düzeyinde ve gerekse de kent genelinde yaşam standartlarını ve yaşanabilir kent olmasını etkileyen temel sorunlar ve bu sorunların çözümüne yönelik öncelikleri belirlenmeye çalışılmıştır.

\section{Materyal ve Yöntem}

\section{Materyal}

Araştırmanın materyalini Türkiye'nin Doğu Anadolu Bölgesi Yukarı Firat Bölümünde yer alan Bingöl kent merkezi oluşturmaktadır. Bingöl'ün Türkiye İstatistik Kurumu (TÜİK) Adrese Dayalı Nüfus Kayıt Sistemi (ADNKS)'e göre 2018 yılı nüfusu 281.205'dir. Kent merkezi nüfusu ise 2000'li yılların başından günümüze kadar sürekli artış göstermiş olup 2000 yılında 68.876, 2010 yılında 87.918 ve 2018 yılında 117.556 olmuştur. Kent merkez nüfusunun il nüfusu içerisindeki payı ise 2000 yılında $\% 27,14,2010$ yılında $\% 34,45$ ve 2018 yılında \%41,8'dir. Nüfus artışı ile birlikte yeni yerleşim yerleri iskâna açılmış, özellikle 2007 yılında Bingöl Üniversitesi'nin kurulması ile kentin gelişimi hızlanmıştır.

Kent merkezinde günümüz itibariyle 15 mahalle bulunmaktadır. Araştırma bulgularının değerlendirilmesinde kent iki bölge halinde ele alınmış- 
tır. Bölge ayrımında kent içerisinden geçmekte olan Çapakçur Vadisi referans alınmış, vadisinin doğu yönünün solunda kalan mahalleler Birinci Bölge, sağında kalan mahalleler İkinci Bölge olarak kabul edilmiştir. Bingöl Üniversitesinin de bulunduğu birinci bölgede yer alan birçok mahalle 2000 yılından sonra kurulmaya başlanmıştır. İkinci bölgede ise İçmeler Mahallesi, Kültür Mahallesi ve İnalı Mahallesi yeni yerleşim alanlarındandır. Buna göre mahallelerin yer aldığı bölge, mahalle yüz ölçümleri ve üç yıllık nüfus verileri Tablo 1'de verilmiştir.

Tablo 1. Bingöl kent merkezi mahalle nüfus dağılımı ve alan büyüklü̈̆̈̈

\begin{tabular}{llllll}
\hline Mahalle İsmi & Bölge & $\begin{array}{l}\text { Mahalle } \\
\text { Yüzölçümü* (ha) }\end{array}$ & 2016 & 2017 & 2018 \\
\hline Karşıyaka Mahallesi & 1 & 126,6 & 4478 & 3953 & 3314 \\
\hline Recep Tayyip Erdoğan Mah. & 1 & 93,2 & 12174 & 11258 & 10522 \\
\hline Saray Mahallesi & 1 & 211,8 & 6135 & 5685 & 5255 \\
\hline Şehit Mustafa Gündoğdu Mah. & 1 & 110,7 & 12259 & 14464 & 15149 \\
\hline Selahaddin-̇̈ Eyyubi Mah. & 1 & 169,7 & 3515 & 3776 & 4758 \\
\hline Bahçelievler Mahallesi & 2 & 78,1 & 7098 & 7457 & 7278 \\
\hline İçmeler Mah. & 2 & 207,9 & 4128 & 4058 & 3723 \\
\hline İnalı Mah. & 2 & 33,7 & 6093 & 7121 & 7375 \\
\hline İnönü Mahallesi & 2 & 78,0 & 7042 & 7449 & 7473 \\
\hline Kültür Mahallesi & 2 & 151,0 & 15976 & 17651 & 18214 \\
\hline Mirzan Mahallesi & 2 & 54,2 & 3397 & 3607 & 3675 \\
\hline Simani Mahallesi & 2 & 24,6 & 8320 & 9727 & 10603 \\
\hline Yeni Mahalle & 2 & 56,5 & 7230 & 7030 & 6783 \\
\hline Yenişehir Mahallesi & 2 & 34,0 & 7720 & 7448 & 6632 \\
\hline Yeşilyurt Mahallesi & 2 & 68,4 & 5799 & 6330 & 6802 \\
\hline Toplam & & 1498,4 & 111.364 & 117.014 & 117.556 \\
\hline
\end{tabular}

* Bingöl Belediyesi verilerinden alınmıştır.

* TUİK ADNKS verileri

Araştırmada Bingöl kentinin kentleşme sürecini etkileyen temel sorun alanları ve öncelikli sorun alanlarının katılımcı yaklaşımla ele alınması amaçlanmıştır. Bu amaçla Bingöl kent merkezinde yaşayan halkın görüşlerinden yararlanılmıştır.

\section{Yöntem}

Araştırmada yöntem olarak birincil kaynaklardan veri toplamada en yaygın olarak kullanılan anket tekniği kullanılmıştır. Anket formu oluşturmadan önce Türkiye ve Dünya'nın değişik bölgelerinde yapılan benzer araştırmalar incelenmiştir. Literatür taramasından yararlanılarak standart anket formu 
oluşturulmuştur. Anketin uygulanabilmesi için Bingöl Üniversitesi Bilimsel Araştırma ve Yayın Etik Kurul Başkanlığı'ndan etik kurul izni alınmıştır (21.06.2018 tarih ve 26 nolu kararı).

Literatür taraması, uzman görüşü ve benzer anketlerin incelenmesi sonucu 13 soruluk anket formu oluşturulmuştur. Anketin örneklem seçiminde basit tesadüfi örneklem yönteminden yararlanılmıştır. Örneklem büyüklügünü belirlemek için ise aşağıdaki formül kullanılmıştır (Gözener ve Sayılı, 2013, s.259).

$$
n=\frac{N \times t^{2} \times p \times q}{d^{2} \times(N-1)+t^{2} \times p \times q}
$$

Formülde; N: hedef kitledeki birey sayısı (117556), p: İncelenen olayın gerçekleşme olasılığı (0.50), q: İncelenen olayın gerçekleşmeme olasılığ (0.50), t: Standart normal dağılım değeri (1.65), d : Örnekleme hatası $(0.05)$ 'dır. Formülde $\% 95$ güven aralığı, \%5 hata payı ve maksimum örnek hacmine ulaşabilmek için $\mathrm{p}=\mathrm{q}=0.5$ olarak alınmış ve örnek hacmi 383 olarak hesaplanmıştır. Ancak uygulamada bu rakamın daha yükseği hedef alınarak 598 kişiye ulaşılmıştır. Anket gönüllü bireylere anketörler aracıllğı ile yüz yüze olmak üzere 2019 Mart-Nisan aylarında uygulanmıştır.

\section{Bulgular}

Araştırma bulguları ankete katılan bireylerin görüşlerine dayanmaktadır. Anket sonuçları dört kısımda ele alınmıştır. Birinci kısımda anket katılımc1ların demografik özellikleri, ikinci kısımda mahalle ölçeğinde fiziki çevre ile ilgili sorun ve öncelikler, üçüncü kısımda kent geneli için yapılan değerlendirme sonuçları açıklanmaktadır. Araştırma bulgularının dördüncü kısmında ise mahalle ve kent ölçeğinde elde edilen sonuçların değişkenler açısından farklılıkları analiz edilmiştir. Ayrıca mahalle ve kent ölçeğinde yapılan değerlendirmelerde Çapakçur Vadisi temel alınarak kent iki bölge halinde ele alınmış ve irdelenmiştir. Birinci bölge ikinci bölgeye göre yeni yerleşim alanlarının daha yoğun olduğu mahalleleri kapsamaktadır.

\section{Katılımcılarn bireysel özellikleri}

Araştırma sonuçlarına etkisi olabilecek bireysel özellikler anket formunda yer almış ve katılımclara sorulmuştur. Ankete katılan bireylerin temel bi- 
reysel özelliklerinden cinsiyet, yaş, medeni hal, eğitim düzeyi, meslek ve gelir seviyesine ilişkin sonuçlar Şekil 1'de verilmiştir. Ankete 264'ü kadın, 334'ü erkek olmak üzere toplam 598 kişi katılmıştır. Anket katılımcılarının 30-45 yaş aralığında, evli ve orta gelirli bireylerin yüksek oranlarda yer aldığ1 görülmüştür.

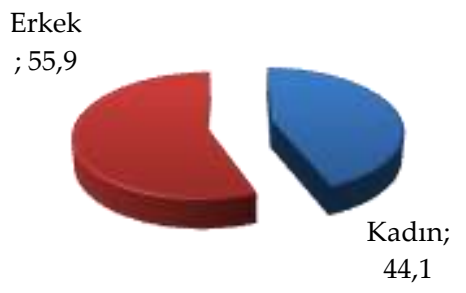

Cinsiyet (\%)
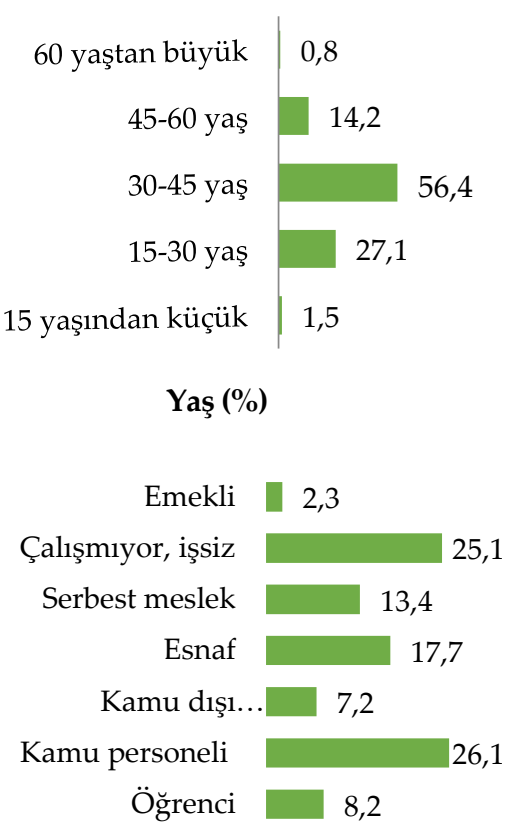

Meslek (\%)

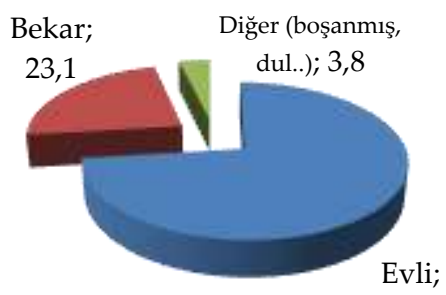

73,1

Medeni hal (\%)

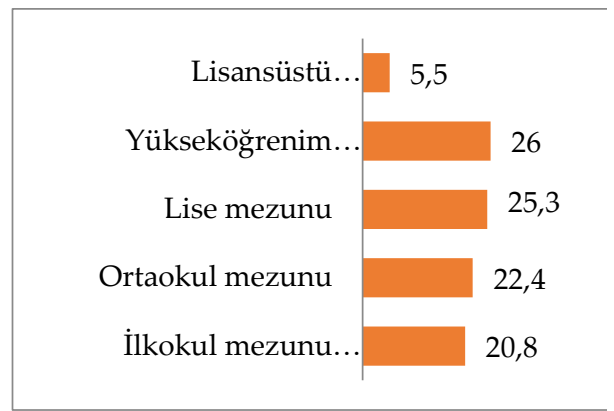

Eğitim (\%)

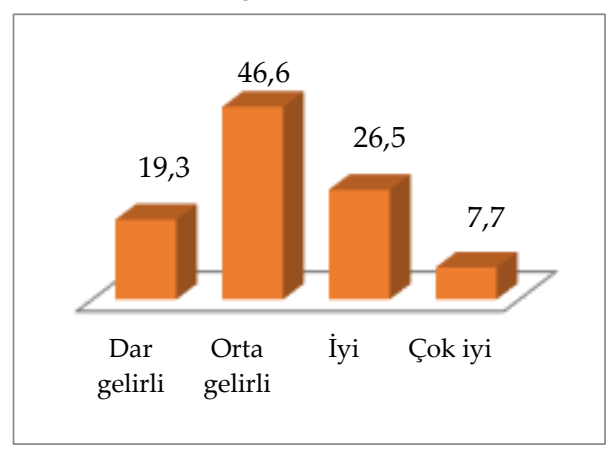

Gelir (\%)

Şekil 1. Katılımcı profiline ilişkin sonuçlar (\%) 
Ankete katılan bireylere ikametgâh özellikleri ve Bingöl'de ikametgâh süreleri de sorulmuştur. Buna göre katılımclardan 383'ü (\%64) apartman dairesinde, 98 'i $(\% 16,4)$ site içerisinde bir dairede, 77 'si $(\% 12,9)$ müstakil evde, 19'u $(\% 3,2)$ sosyal tesis-yurt veya pansiyonda ikamet etmektedir. 21 Kişi $(\% 3,5)$ ise bunların dışında ikamet bildirmektedir. "Kaç yıldır Bingöl'de ikamet etmektesiniz?" sorusuna katılımciların \%72,9'u 10 yıldan fazla, \%11,4'ü 5-10 yıl arası, \%13,5'i 1-5 yıl arası ve \%2,2 kısa süreli (misafir ya da bir yıldan az) cevabını vermiştir.

\section{Mahalle ölçeğinde kentsel sorunlar ve öncelikler}

Araştırmaya katılan bireylere yaşadığı mahallede günlük hayatı etkileyen sorunlar ve kullanım alanlarının yeterliliği sorulmuş ve elde edilen sonuçların \%'lik karşılığ 1 Tablo 2'de verilmiştir.

Tablo 2. Mahalle ölçeğinde sorun alanları sonuçlan (\%)

\begin{tabular}{|c|c|c|c|c|}
\hline \multirow[t]{2}{*}{ S.N } & \multirow[t]{2}{*}{ Sorun alanı/ kullanım alanı yeterliliği } & \multicolumn{3}{|c|}{ Seçenekler $(\%)$} \\
\hline & & Var & Yok & Orta \\
\hline 1 & Trafik sorunu (trafik akışı ve yoğunluğu) & 58,5 & 20,8 & 20,7 \\
\hline 2 & Toplu ulaşım sıkıntısı & 61,6 & 24 & 14,4 \\
\hline 3 & Otopark sorunu, araç park etme ile ilgili sorunlar & 73,1 & 15,3 & 11,6 \\
\hline 4 & Gürültü sorunu & 51,2 & 26,1 & 22,7 \\
\hline 5 & Çarpık ve düzensiz yapılaşma & 72,7 & 12,9 & 14,4 \\
\hline 6 & Çevre kirliliği, atıklar, çöp sorunu & 77,7 & 9,2 & 13,1 \\
\hline 7 & Hava kirliliği & 51,2 & 26,6 & 22,2 \\
\hline \multirow[t]{2}{*}{8} & Su, kanalizasyon.. vb altyapı sorunları & 64,5 & 21,3 & 14,2 \\
\hline & & Estetik & $\begin{array}{l}\text { Estetik } \\
\text { değil }\end{array}$ & Orta \\
\hline 9 & Mahalle estetiği & 16,3 & 56,1 & 27,6 \\
\hline \multirow[t]{2}{*}{10} & $\begin{array}{l}\text { Mimari yapıların (binaların) birbiriyle ve çevresiyle } \\
\text { uyumu }\end{array}$ & 16,1 & 64,1 & 19,8 \\
\hline & & Yeterli & Yetersiz & Orta \\
\hline 11 & Yeşil alanlar (park, piknik alanı, çay bahçesi,...) & 6,5 & 84,6 & 8,9 \\
\hline 12 & Çocuk oyun alanları & 7,4 & 81,5 & 11,1 \\
\hline 13 & Gençler için spor ve oyun imkânları & 8 & 82,1 & 9,9 \\
\hline 14 & Araç yolları (yol genişliği, zemini, güzergâhı...) & 11,6 & 71,4 & 17 \\
\hline 15 & $\begin{array}{l}\text { Yaya yolları ve kaldırımlar (kaldırım genişliği, } \\
\text { zemini, yürüme ve dinlenmeye uygunluğu) }\end{array}$ & 10,1 & 77,3 & 12,6 \\
\hline 16 & $\begin{array}{l}\text { Kent mobilyaları (çöp kutusu, oturma birimleri, } \\
\text { aydınlatmalar) sayı ve nitelik bakımından }\end{array}$ & 9,4 & 77,7 & 12,9 \\
\hline
\end{tabular}


Tablo 2'de verilen sonuçlara göre katılımcilar günlük hayatı etkileyen sorunların başında çevre kirliliği, atıklar ve çöp sorununun geldiğini vurgulamaktadır. İkinci sırada ise otopark sorunu ile karşılaşıldığı bildirilmiştir. Bunun yanında kentin diğer sorun alanların da yüksek oranda karşılaşıldığ ve gündelik hayatı olumsuz etkilediği görülmektedir. Kullanım alanları bakımından ise katılımcılar yeşil alan yetersizliğini çok yüksek oranda $(\% 84,6)$ sorun olarak görmektedir. Gençler için spor olanaklarının ve çocuk oyun alanlarının yetersiz olduğuna ilişkin görüşlerde de yüksek oranlar dikkat çekmektedir. 16 Madde üzerine yapılan değerlendirme sonuçlarına göre kentte gürültü kirliliği, hava kirliliği ve mahalle estetiği diğer seçeneklere göre daha olumlu bulunmuştur. Bu konularda dahi katılımcıların \%5060 oranında sorun bildirdiği dikkat çekmektedir.

Araştırma kapsamında katılımcılara mahallelerinde öncelikli olarak çözülmesi istenilen üç sorunun ne olduğu sorulmuş ve bu sorunların önceliklendirilmesi istenilmiştir. Buna göre elde edilen sonuçlar Tablo 3'de verilmiştir.

Tablo 3. Mahalle ölçeğinde öncelikli çözüm önerileri

\begin{tabular}{|c|c|c|c|c|c|c|c|c|c|}
\hline \multirow{3}{*}{ Sorunlar } & \multicolumn{8}{|c|}{ Öncelik Stralaması } & \multirow[t]{3}{*}{ Ö.S. } \\
\hline & \multicolumn{2}{|c|}{ Birinci öncelik } & \multicolumn{2}{|c|}{ İkinci öncelik } & \multicolumn{2}{|c|}{ Üçüncü öncelik } & \multicolumn{2}{|c|}{ Toplam } & \\
\hline & $N$ & $\%$ & $N$ & $\%$ & $N$ & $\%$ & $N$ & $\%$ & \\
\hline Yeşil alan yetersizliği & 233 & 39 & 56 & 9,4 & 62 & 10,4 & 351 & 58,8 & 1 \\
\hline Çevre kirliliği, atıklar, çöp sorunu & 54 & 9 & 72 & 12 & 106 & 17,7 & 232 & 38,7 & 2 \\
\hline Çocuk oyun alanlarının yetersizliği & 35 & 5,9 & 112 & 18,7 & 70 & 11,7 & 217 & 36,3 & 3 \\
\hline Park, otopark sorunu & 53 & 8,9 & 80 & 13,4 & 81 & 13,5 & 214 & 35,8 & 4 \\
\hline Trafik sorunu & 78 & 13 & 89 & 14,9 & 29 & 4,8 & 196 & 32,7 & 5 \\
\hline Yol, su, kanalizasyon.. vb altyapı sorunları & 32 & 5,4 & 41 & 6,9 & 64 & 10,7 & 137 & 23 & 6 \\
\hline Çarpık ve düzensiz yapılaşma & 32 & 5,4 & 55 & 9,2 & 44 & 7,4 & 131 & 22 & 7 \\
\hline Araç ve yaya yolları ile ilgili sorunlar & 28 & 4,7 & 23 & 3,8 & 66 & 11 & 117 & 19,5 & 8 \\
\hline Görüntü kirliliği (Kent estetiği) & 20 & 3,3 & 41 & 6,9 & 38 & 6,4 & 99 & 16,6 & 9 \\
\hline Gürültü kirliliği & 17 & 2,8 & 24 & 4 & 27 & 4,5 & 68 & 11,3 & 10 \\
\hline Diğer & 16 & 2,6 & 5 & 0,8 & 11 & 1,9 & 32 & 5,3 & 11 \\
\hline
\end{tabular}

Yukarıdaki sonuçlara göre ankete katılan bireyler "Yeşil alan yetersizliği" sorununun çözümünü birinci öncelik olarak en yüksek oranda (\%39) talep ettikleri görülmüştür. "Çocuk oyun alanlarının yetersizliği" sorununu ikinci öncelik, "Çevre kirliliği, atıklar, çöp sorununu" ise üçüncü öncelikli çözülmesi gereken sorun olarak görmektedir. Toplamda ise yeşil alan yetersizliği birinci sırada, çevre kirliliği, atıklar ve çöp sorununu ikinci sırada ve 
çocuk oyun alanları yetersizliğini ise üçüncü sırada çözülmesi gereken sorunlar olarak görmektedirler. Özellikle yeşil alan yetersizliğinin giderilmesi ile ilgili katılımcıların en yüksek oranda $(\% 58,8)$ talep ettikleri dikkat çekmektedir.

\section{Kent geneli için sorun ve öncelikler}

Mahalle ölçeği için yapılan değerlendirmeler kent geneli için de yapılmıştır. Buna göre anket katılımcıları kent için belirlenen sorunlara katılma yüzdeleri Tablo 4'de verilmiştir.

Tablo 4. Kent geneli için yapılan değerlendirme sonuçları (\%)

\begin{tabular}{|c|c|c|c|c|}
\hline \multirow[t]{2}{*}{ S.N } & \multirow[t]{2}{*}{ Sorun alanı/ kullanım alanı yeterliliği } & \multicolumn{3}{|c|}{ Seçenekler (\%) } \\
\hline & & Var & Yok & Orta \\
\hline 1 & Trafik sorunu (trafik akışı ve yoğunluğu) & 70,7 & 13,4 & 15,9 \\
\hline 2 & Toplu ulaşım sıkıntısı & 68,2 & 17,9 & 13,9 \\
\hline 3 & Otopark sorunu, araç park etme ile ilgili sorunlar & 81,6 & 8,1 & 10,3 \\
\hline 4 & Gürültü sorunu & 55,8 & 20,5 & 23,7 \\
\hline 5 & Çarpık ve düzensiz yapılaşma & 75,7 & 9,4 & 14,9 \\
\hline 6 & Çevre kirliliği, atıklar, çöp sorunu & 79,2 & 8,1 & 12,7 \\
\hline 7 & Hava kirliliği & 51,4 & 24,8 & 23,8 \\
\hline \multirow[t]{2}{*}{8} & Su, kanalizasyon. vb. altyapı sorunları & 67,7 & 15,8 & 16,5 \\
\hline & & Estetik & Estetik değil & Orta \\
\hline 9 & Kent estetiği & 15,2 & 64,2 & 20,6 \\
\hline \multirow[t]{2}{*}{10} & $\begin{array}{l}\text { Mimari yapıların (binaların) birbiriyle ve çevresiyle } \\
\text { uyumu }\end{array}$ & 13,1 & 69,2 & 17,7 \\
\hline & & Yeterli & Yetersiz & Orta \\
\hline 11 & Yeşil alanlar (park, piknik alanı, çay bahçesi,...) & 7,2 & 81,4 & 11,4 \\
\hline 12 & Çocuk oyun alanları & 6 & 80,9 & 13,1 \\
\hline 13 & Gençler için spor ve oyun imkânları & 5,9 & 81,7 & 12,4 \\
\hline 14 & Araç yolları (yol genişliği, zemini, güzergâhı...) & 7,4 & 75,5 & 17,1 \\
\hline 15 & $\begin{array}{l}\text { Yaya yolları ve kaldırımlar (kaldırım genişliği, } \\
\text { zemini, yürüme ve dinlenmeye uygunluğu) }\end{array}$ & 7,9 & 76,5 & 15,6 \\
\hline 16 & $\begin{array}{l}\text { Kent mobilyaları (çöp kutusu, oturma birimleri, } \\
\text { aydınlatmalar) sayı ve nitelik bakımından }\end{array}$ & 7,6 & 76,3 & 16,1 \\
\hline
\end{tabular}

Katılımclların kent geneli için yaptığı değerlendirmede en yüksek oranda otopark sorununu görmüşlerdir. Kullanım alanlarının yeterliliği ile ilgili değerlendirmede ise gençler için spor ve oyun olanakları en yüksek oranda yetersiz bulunmuştur. Bunların yanı sıra yeşil alan yetersizliği, çocuk oyun alanları yetersizliği ve çevre kirliliği sorunu katılımcılar tarafından yüksek 
oranlarda olumsuz bulunmuştur. Katılımcıların mahalle ölçeğinde ve kent geneli için yaptığı değerlendirmelerde benzer olumsuzluklar görülmesine karşılık kent geneli için yapılan değerlendirmelerde daha yüksek oranlarda puanlama yapıldığı görülmüştür. Özellikle trafik, otopark, ulaşım ve araç yolları ile sorunların kent geneli için daha yüksek oranlarda sorun olarak görüldüğü göze çarpmaktadır.

Kent geneli için katılımcıların öncelikleri de belirlenmiştir (Tablo 5). Buna göre katılımcllar kent genelinde birinci öncelikli çözülmesi gereken sorun olarak yeşil alan yetersizliğini, ikinci öncelikli çözülmesi gereken sorun olarak çocuk oyun alanı yetersizliğini ve üçüncü öncelikli çözülmesi gereken sorun olarak çevre kirliliği ve çöp sorununu görmektedir. Toplamda ise yeşil alan yetersizliği birinci sırada, çevre kirliliği, atıklar ve çöp sorununu ikinci sırada ve trafik sorunu üçüncü sırada çözülmesi gereken sorunlar olarak görülmektedir. Mahalle ölçeğinde yapılan değerlendirmeden farklı olarak katılımclar trafik ve otopark sorununun çözülmesini kent geneli için daha öncelikli görmektedir.

Tablo 5. Kent geneli için öncelikli çözüm önerileri

\begin{tabular}{|c|c|c|c|c|c|c|c|c|c|}
\hline \multirow{3}{*}{ Sorunlar } & \multicolumn{8}{|c|}{ Öncelik Sıralaması } & \multirow[t]{3}{*}{ Ö.S. } \\
\hline & \multicolumn{2}{|c|}{ Birinci öncelik } & \multicolumn{2}{|c|}{ İkinci öncelik } & \multicolumn{2}{|c|}{ Üçüncü öncelik } & \multicolumn{2}{|c|}{ Toplam } & \\
\hline & $N$ & $\%$ & $N$ & $\%$ & $N$ & $\%$ & $N$ & $\%$ & \\
\hline Yeşil alan yetersizliği & 193 & 32,3 & 64 & 10,7 & 63 & 10,5 & 320 & 17,8 & 1 \\
\hline Çevre kirliliği, atıklar, çöp sorunu & 66 & 11 & 71 & 11,9 & 98 & 16,4 & 235 & 13,1 & 2 \\
\hline Trafik sorunu & 103 & 17,2 & 87 & 14,5 & 33 & 5,5 & 223 & 12,4 & 3 \\
\hline Park, otopark sorunu & 45 & 7,5 & 84 & 14 & 86 & 14,4 & 215 & 12,0 & 4 \\
\hline Çocuk oyun alanlarının yetersizliği & 37 & 6,2 & 96 & 16,1 & 61 & 10,2 & 194 & 10,8 & 5 \\
\hline Yol, su, kanalizasyon.. vb altyapı sorunları & 34 & 5,7 & 47 & 7,9 & 65 & 10,9 & 146 & 8,1 & 6 \\
\hline Çarpık ve düzensiz yapılaşma & 36 & 6 & 53 & 8,9 & 55 & 9,2 & 144 & 8,0 & 7 \\
\hline Araç ve yaya yolları ile ilgili sorunlar & 31 & 5,2 & 28 & 4,7 & 65 & 10,9 & 124 & 6,9 & 8 \\
\hline Görüntü kirliliği (Kent estetiği) & 19 & 3,2 & 37 & 6,2 & 42 & 7 & 98 & 5,5 & 9 \\
\hline Gürültü kirliliği & 21 & 3,5 & 30 & 5 & 20 & 3,3 & 71 & 4,0 & 10 \\
\hline Diğer & 13 & 2,2 & 1 & 0,2 & 10 & 1,7 & 24 & 1,3 & 11 \\
\hline
\end{tabular}

\section{Anket sonuçlarının karşılaştırmalı analizi}

Bu kısımda anket sonuçlarından elde edilen bulguların bazı değişkenler bakımından farklılaşıp farklılaşmadıklarına ilişkin analizler yer almaktadır. Katılımcıların cinsiyet, yaş, meslek, medeni hal, gelir, ikametgâh ve eğitim düzeyleri ile mahalle ve kent geneli için belirtilen sorun alanlarına katılma 
düzeyleri arasında bir ilişkinin olup olmadığı belirlenmiştir. Ayrıca kent iki bölge halinde ele alınarak eski ve yeni yerleşim özelliklerinin ve sorun alanlarının benzeşen ve ayrılan yönleri belirlenmeye çalışılmıştır. Analize tabi tutulan soruların kategorik veri olması nedeniyle değişkenler bakımından sonuçların analizinde Pearson Chi Square (Ki kare) testinden yararlanılmıştır. Test yapılırken beklenen değerlerinin 5 'ten büyük olmasına dikkat edilmiş ve beklenen değerleri 5 'ten küçük olan sonuçlar değerlendirmeye alınmamiştır.

Mahalle ölçeğinde sorun alanlarına ilişkin yapılan Ki kare testi sonuçlarına göre yaş, ikametgâh ve Bingöl'de bulunma süresinin katılımcıların kentsel sorun alanları ile ilgili yaptıkları değerlendirmeyi etkilemediği ve gruplar arasında fark oluşmadığı belirlenmiştir $(p>, 05)$. Bunun yanında Tablo 2'de katılımcılar tarafından değerlendirilen 16 sorun alanından 9'unda değişkenler bakımından değerlendirmenin farklılaşmadığı, diğer 7 sorun alanı üzerine yapılan değerlendirmede ise bazı değişkenler açısından sonuçların farklılaştı̆̆ı görülmüştür (Tablo 6).

Tablo 6. Mahalle düzeyinde yapılan değerlendirmede gruplar arası fark analizi (Ki kare analizi)

\begin{tabular}{|c|c|c|c|c|c|c|}
\hline \multirow[b]{2}{*}{ Sorun alanları } & \multicolumn{6}{|c|}{ Önem değeri (p) } \\
\hline & Bölge & Cinsiyet & Meslek & Medeni hal & Gelir & $\begin{array}{l}\text { Eğitim } \\
\text { düzeyi }\end{array}$ \\
\hline $\begin{array}{l}\text { Trafik sorunu (trafik akışı, } \\
\text { yoğunluğu,) }\end{array}$ & $0,00^{*}$ & $0,00^{*}$ & $0,00^{*}$ & 0,47 & $0,00^{*}$ & 0,26 \\
\hline Toplu ulaşım sıkıntısı & $0,03^{*}$ & 0,08 & 0,29 & $0,01^{*}$ & 0,09 & 0,84 \\
\hline $\begin{array}{l}\text { Otopark sorunu, araç } \\
\text { park etme ile ilgili sorunlar }\end{array}$ & $0,04^{*}$ & 0,08 & $0,00^{*}$ & 0,45 & 0,65 & 0,18 \\
\hline $\begin{array}{l}\text { Çarpık ve düzensiz } \\
\text { yapılaşma }\end{array}$ & 0,26 & 0,90 & $0,02^{*}$ & 0,20 & $0,01^{*}$ & 0,11 \\
\hline $\begin{array}{l}\text { Çevre kirliliği, atıklar, çöp } \\
\text { sorunu }\end{array}$ & 0,97 & 0,94 & 0,81 & 0,43 & 0,42 & $0,03^{*}$ \\
\hline Hava kirliliği & 0,29 & 0,49 & 0,77 & 0,17 & 0,06 & $0,01^{*}$ \\
\hline $\begin{array}{l}\text { Su, kanalizasyon.. vb } \\
\text { altyapı sorunları }\end{array}$ & 0,09 & 0,43 & 0,53 & 0,18 & 0,11 & $0,05^{*}$ \\
\hline
\end{tabular}

${ }^{*} \mathrm{p}<0,05$

Araştırma sonuçlarının bölge ayrımı göz önünde bulundurularak yapılan değerlendirmede iki bölge arasında trafik, toplu ulaşım ve otopark sorunu bakımından farklılık bulunmuştur. Yeni yerleşim alanlarının daha yoğun olduğu birinci bölgede bulunan mahallelerde trafik, toplu ulaşım 
sıkıntısı ve otopark sorununun ikinci bölgeye göre daha yoğun olarak yaşandığı katılımcı görüşlerinden anlaşılmaktadır. Bölge değişkenine göre diğer sorun alanlarında bir birine yakın sonuçlar elde edilmiştir. Trafik sorunu ile ilgili katılımcıların yaptığı değerlendirmede cinsiyet, meslek ve gelir düzeyi değişkenlerine göre sonuçların farklılaştığı belirlenmiştir. Buna göre cinsiyet bakımından "erkek" katılımclar, meslek bakımından "öğrenciler" ve gelir düzeyi bakımından ise "orta gelirli" grup diğer gruplara göre mahallelerinde trafik sorunu ile ilgili daha olumsuz görüsslere sahiptirler.

Tablo 6'ya göre mahalle ölçeğinde günlük hayatı olumsuz etkileyen sorun alanları üzerine yapılan değerlendirmede bazı grupların daha yüksek oranda olumsuzluk bildirdiği görülmüştür. Toplu ulaşım sorunlarından "medeni hal-bekâr" grubu, otopark sorunundan "meslek-öğrenci" grubu, çarpık ve düzensiz yapılaşmadan "meslek-kamu personeli" ve "gelir düzeyi-çok iyi" grubu kendi grupları içerisinde daha yüksek oranda olumsuz görüş bildirmiştir. Eğitim seviyesi değişkeni bakımından ise lisansüstü mezunlar çevre kirliliğini, ortaokul mezunları hava kirliliğini ve ilkokul mezunları alt yapı sorunlarını daha önemli bulmaktadırlar.

Kent geneli için katılımcıların yapmış olduğu değerlendirmede gruplara göre sorun tespitinde farklılaşmanın oluşup oluşmadı̆̆ı da analiz edilmiştir. Analiz sonuçlarına göre cinsiyet, yaş, eğitim düzeyi, meslek ve gelir düzeyi değişkenleri sorun alanı tespitinde fark meydana getirmişken bölge, medeni hal, ikametgâh çeşidi ve ikametgâh süresine bağlı olarak sonuçlar farklılaşmamıştır (Tablo 7).

Kent geneli için değerlendirilmesi istenilen 16 adet sorun alanından toplu ulaşım sıkıntısı, otopark sıkıntısı, çevre kirliliği-çöp sorunu, yeşil alan yetersizliği, çocuk oyun alanı yetersizliği ve gençler için spor olanaklarının yetersizliği ile ilgili puanlamada gruplar (değişkenler) arasında homojen bir durum söz konusudur. Bu durum söz konusu sorun alanları üzerinde büyük oranda fikir birliğinin olduğunu göstermektedir. Diğer sorun alanlarında ise bazı grupların kendi içinde daha yüksek oranda olumsuz fikre sahip oldukları görülmektedir. Özellikle eğitim ve gelir düzeyi değişkenleri sorun alanlarının tespitinde daha heterojen bir sonuç ortaya koymaktadır. 
Tablo 7. Kent geneli sorun alanlarnın değerlendirilmesinde katılımcı gruplara göre anlamlılık testi sonuçlan (Ki kare analizi)

\begin{tabular}{|c|c|c|c|c|}
\hline \multirow[b]{2}{*}{ Değişkenler } & \multirow[b]{2}{*}{ Sorun alanlan } & \multicolumn{2}{|c|}{ Analiz sonuçlan } & \multirow{2}{*}{$\begin{array}{l}\text { En yüksek } \\
\text { oranda olumsuz } \\
\text { görüş bildiren grup }\end{array}$} \\
\hline & & $X^{2}$ & $p$ & \\
\hline Cinsiyet & $\begin{array}{l}\text { Mimari yapıların (binaların) } \\
\text { birbiriyle ve çevresiyle uyumu }\end{array}$ & 11,16 & 0,04 & Erkek \\
\hline Yaş & Toplu ulaşım sıkıntısı & 15,41 & 0,02 & $15-30$ yaş \\
\hline \multirow{6}{*}{$\begin{array}{l}\text { Eğitim } \\
\text { düzeyi }\end{array}$} & $\begin{array}{l}\text { Otopark sorunu, araç park etme } \\
\text { ile ilgili sorunlar }\end{array}$ & 22,39 & 0,00 & $\begin{array}{l}\text { Lisansüstü } \\
\text { öğrenim mezunu }\end{array}$ \\
\hline & Gürültü sorunu & 23,49 & 0,00 & $\begin{array}{l}\text { Lisansüstü } \\
\text { öğrenim mezunu }\end{array}$ \\
\hline & Çarpık ve düzensiz yapılaşma & 16,99 & 0,03 & $\begin{array}{l}\text { Yükseköğrenim } \\
\text { mezunu }\end{array}$ \\
\hline & Hava kirliliği & 17,42 & 0,03 & Ortaokul mezunu \\
\hline & $\begin{array}{l}\text { Mimari yapıların (binaların) } \\
\text { birbiriyle ve çevresiyle uyumu }\end{array}$ & 24,60 & 0,00 & Ortaokul mezunu \\
\hline & Kent mobilyalarının yeterliliği & 15,97 & 0,04 & Ortaokul mezunu \\
\hline \multirow{3}{*}{ Meslek } & $\begin{array}{l}\text { Trafik sorunu } \\
\text { (trafik akışı, yoğunluğu,...) }\end{array}$ & 28,75 & 0,00 & Esnaf \\
\hline & Hava kirliliği & 25,57 & 0,01 & Emekli \\
\hline & $\begin{array}{l}\text { Mimari yapıların (binaların) } \\
\text { birbiriyle ve çevresiyle uyumu }\end{array}$ & 25,88 & 0,01 & Öğrenci \\
\hline \multirow{7}{*}{ Gelir } & $\begin{array}{l}\text { Trafik sorunu (trafik akışı, } \\
\text { yoğunluğu,...) }\end{array}$ & 12,62 & 0,04 & Dar gelirli \\
\hline & Hava kirliliği & 24,09 & 0,00 & Çok iyi \\
\hline & Kent estetiği & 15,85 & 0,02 & Dar gelirli \\
\hline & $\begin{array}{l}\text { Mimari yapıların (binaların) } \\
\text { birbiriyle ve çevresiyle uyumu }\end{array}$ & 13,34 & 0,04 & Dar gelirli \\
\hline & $\begin{array}{l}\text { Araç yolları } \\
\text { (yol genişliği, zemini, güzergâhı...) }\end{array}$ & 22,57 & 0,00 & Dar gelirli \\
\hline & $\begin{array}{l}\text { Yaya yolları ve kaldırımlar } \\
\text { (kaldırım genişliği, zemini, yürüme } \\
\text { ve dinlenmeye uygunluğu) }\end{array}$ & 18,35 & 0,01 & Dar gelirli \\
\hline & $\begin{array}{l}\text { Kent mobilyaları (çöp } \\
\text { kutusu, oturma birimleri, aydınlat- } \\
\text { malar) sayı ve nitelik bakımından }\end{array}$ & 13,18 & 0,04 & Dar gelirli \\
\hline
\end{tabular}

\section{Tartışma ve Sonuç}

Günümüzde kentlerin insanlara ekonomik, sosyal ve kültürel olanaklar sunabilmesi için önemli çabalar sarf edilmektedir. Özellikle Türkiye'de 2000'li yıllardan sonra insanların ulaşım, altyapı, sağlık, güvenlik, rekreasyon, vb... hizmetlere erişimini kolaylaştırmak için oldukça önemli yatırım- 
lar yapılmakta ve kentler her geçen gün daha yaşanabilir hale gelmektedir (Yüksel ve Yeliş, 2017, s.689). Aynı zamanda yapılan bu yatırımlar ile kentlerin kırsala oranla cazibesi artmış ve kırsal kesimlerden kentlere doğru yoğun göçün yaşanmasına neden olunmuştur. Bunun yanında kırsal kesimde zor yaşam koşulları, topraklardan beklenen verimin alınamaması, ekonomik koşulların uygun olmaması, eğitim ve sağlık hizmetlerinin yetersizliği gibi farklı unsurlar kırsal kesimden kente doğru göçün beklenenin üzerinde gerçekleşmesi sonucunu doğurmuştur (Kiziroğlu, 2003, s.56). Yoğun göç ile birlikte nüfusun temel gereksinimlerini karşlamada çeşitli zorluklar kentlerin sürdürülebilir yönetimini sıkıntıya sokmaktadır. Özellikle gelişmekte olan ülkelerde birçok kent için sürdürülebilir kentsel gelişimine yönelik teorik veya politik düzeyde planlama yaklaşımı ortaya koyulamamıştır. Kentlerin sürdürülebilir büyümesine yönelik stratejik amaç ve hedefler belirlenememiştir. Diğer taraftan sosyal, politik ve ekonomik olanakları yetersiz olan kentlerde ideal sürdürülebilir kentsel gelişimi sağlamak oldukça zorlu bir süreçtir. Bu durumda kentleri mümkün olabildiğince az sürdürülemez kılmak için çaba gösterilmelidir (Freire, 2006, s.12; Dave, 2010, s.24).

Türkiye'nin birçok kentinde olduğu gibi 2000'li yıllardan sonra Bingöl'de de kırsal kesimden kent merkezine yoğun göç meydana gelmiş ve bu göç sonucunda kent yerleşimi de oldukça büyümüştür. Esen (2019, s.114)'e göre yakın zamanda kent merkezinde mevcut arazilerin bu büyümeyi karşılayamayacağı ve kent yakını tarım alanları ve orman alanları üzerine baskı uygulayacağı öngörülmektedir. Bunun yanında araştırma alanında kentsel büyüme ile birlikte doğal ve beşeri faktörlerin neden olduğu çok farklı çevre sorunları ortaya çıkmıştır (Soylu, 2009, s.101). Nitekim Bingöl kentinin gelişim sürecinde gerek fiziki çevreden kaynaklanan gerekse de beşeri unsurların ortaya çıkardığı temel sorunların yerel halk görüşleri ile belirlendiği bu araştırmanın sonuçları da bunu doğrular niteliktedir. Her şeyden önce araştırmaya katılan bireyler kentte sorunların çok yönlü olduğunu ve sorun derecesinin ise yüksek olduğunu vurgulamaktadırlar.

Katılımcıların hem yaşadıkları mahalle ölçeğinde hem de kent genelinde belirledikleri sorunların başında yeşil alan yetersizliği öne çıkmaktadır. Katılımcılar mahalle ölçeğinde \%84,6, kent genelinde ise \%81,4 oranında yeşil alanların yetersizliğini vurgulamaktadır. Üstelik katılımcıların bireysel özelliklerine göre değerlendirmenin farklılaşmadığ1 ve tüm grupların bu konu- 
da fikir birliğine vardıkları görülmektedir. Araştırma alanında yeşil alan yetersizliğine yönelik Doğan ve Yılmaz (2019, s.543) tarafından yapılan araştırmada 2000 yılından 2017 yıla kadar olan süreçte kentsel alanlar 243 ha artmış olduğu halde yeşil alan varlığında 92 ha'lık azalma meydana gelmiştir. Ayrıca Tatlılıoğlu $(2015$, s.48) ve Soylu $(2009$, s.88) tarafından yapılan çalışmalarda kentin yeşil alan yetersizliğine vurgu yapılmaktadır. Yüksel ve Yeşil (2017, s.690) ise Ordu'da yapılan araştırmaya katılan bireyler rekreasyon alanlarının yetersizliğini en önemli sorun olarak görmektedirler. Oysa kamusal yeşil alanlar kentsel yapının önemli bir parçası olarak bilinir ve kentsel sürdürülebilirliğin sağlanmasında önemli görevler üstlenirler. Kamusal yeşil alan varlığı ile kentsel yaşam kalitesi arasında güçlü bir bağ bulunmaktadır (Lopes ve Camanho, 2013, s.765). Özünde kent insanı kamusal yeşil alanları korunarak gelecek nesillere bırakılması gereken kültürel bir miras olarak görmekte ve yerleşim alanlarında daha fazla miktarda yeşil alan mevcudiyetini olumlu görmektedir (Bonnes vd., 2007, s.74; Jennings, vd., 2012, s.4). Buna yönelik araştırmaya katılan halkın kentsel fiziki çevrede birinci önceliğini de yeşil alanların iyileştirilmesi oluşturmaktadır. Ankete katılan bireylerin \%58,8'i mahalle ölçeğinde, $\% 53,5^{\prime} \mathrm{i}$ ise kent genelinde yeşil alan yetersizliğinin birinci derecede çözülmesi gereken sorun olarak tanımlamaktadırlar.

Yeşil alan yetersizliğinden sonra gençler için spor ve oyun alanlarının yetersizliği Bingöl halkının ikinci sırada en yüksek oranda sorun olarak gördüğü husustur. Araştırmaya katılan bireylerin \%82,1'i mahalle ölçeğinde, $\% 81,7^{\prime}$ si kent genelinde gençler için spor ve oyun olanaklarının yetersizliğine vurgu yapmaktadır. Benzer olarak çocuk oyun alanları da yüksek oranda (mahallede \%81,5, kent genelinde \%80,9) yetersiz görülmüştür. Ancak katılımcıların öncelikli çözülmesi gereken hususlar içerisinde gençler için oyun ve spor olanaklarının iyileştirilmesi üst sıralarda yer almazken çocuk oyun alanlarının iyileştirilmesi mahalle ölçeğinde üçüncü sırada kent genelinde beşinci sırada yer almaktadır.

Kentsel çevre kalitesinin değerlendirilmesine çok disiplinli ve çok boyutlu bir süreci içermektedir. Dolayısıyla arzu edilen kentsel çevre kalitesinin sağlanması için sistemde tüm aktörlerin iyi yönetilmesi gerekmektedir. Bonnes et al. (2007; s.73)'e göre ekosistem yaklaşımında sistemin bir bölümündeki değişikliklerin veya olumsuzlukların diğer bölümler üzerinde etkisi olacaktır. Bu kapsamda esasında araştırma alanında katılımcilar tara- 
fından yüksek oranlarda yetersiz olarak değerlendirilen yeşil alanlar, gençler için spor alanları ve çocuklar için oyun alanlarının yetersizliği gibi sorunlar diğer sorunlara da yol açmış olacağı değerlendirilmektedir. Olumsuz çevre koşulları altında bireylerin çevreye karşı daha olumsuz tutum sergiledikleri düşünüldüğünde Bingöl'de kentsel sorun alanlarının fazlalığı dikkat çekmektedir. Nitekim katılımcılar çevre kirliliği, atıklar ve çöp sorunu ile ilgili yüksek oranlarda rahatsızlıklarını öne çıarmış ve ikinci öncelikli çözülmesi gereken sorun olarak belirtmişlerdir. Esasen Çizelge 2 ve Çizelge 4'de ki sonuçlara bakıldığında kentsel çevre sorunlarına ilişkin oransal olarak farklılık bulunmasına karşılık tüm konularda belirli oranlarda problemlerin yaşanıldığ görülmektedir. 16 Sorun alanı ile ilgili yapılan değerlendirmenin ortalama sonuçlarına göre katılımcların sadece \%11-38 arasında yaşadıkları mahalleleri için, \%12-37 arasında ise kent geneli için sorun bildirilmemiştir.

Araştırma alanında ve Türkiye'nin diğer illerinde fiziki çevrede yaşanan çevre sorunlarının kaynağı mevcut ulusal-yerel politikalar ve onların beraberinde getirdiği uygulamalardır. Kentleşme ve çevre sorunları çevrenin yönetsel, ekonomik ve kültürel sürecinin belirlediği politikaların bir sonucudur (Kocalar, 2019, s.30). Kentlerin sürdürülebilir gelişimi için politikalar ortaya koymak ve uygulamak devletin görevidir. Bu doğrultuda sağlıklı ve düzenli kentleşmeyi gerçekleştirmek, halkın sağlıklı ve dengeli bir çevrede yaşamasını sağlamak, çevrenin geliştirilmesi, çevre sağlığının korunması ve çevre kirlenmesi ile şehirlerin özelliklerini gözeten bir planlamanın yapılması devletin anayasal görevleri içerisinde yer almaktadır (Kiziroğlu, 2003, s.66). Devlet adına yerelde ortaya çıkan çevre sorunlarının giderilmesinden ve kentlerin planlı bir şekilde gelişiminden yerel yönetimler sorumludur. Bu kapsamda yerel yönetimler gelecekte kente gelmesi muhtemel nüfusu da göz önünde bulundurarak plan ve programlar oluşturur ve uygularlar (Toprak, 2017, s.173). Genel bir değerlendirme olması bakımından katılımc1lara Bingöl'ün kentleşme süreci sorulmuş ve katılımcıların Bingöl'ün kentsel gelişim sürecini plansız olarak nitelendirdikleri görülmüştür. Katılımcıların \%40'1 kentin gelişimini hılı-plansız, \%41,6's1 yavaş-plansız, \%6,2'si hızl1planlı, \%8,7'si yavaş-planlı ve \%3,5'i her bakımdan uygun olarak değerlendirmişlerdir.

Araştırma alanında katılımcilarında belirlemiş olduğu problemlerin kentsel yaşam standardı üzerinde olumsuz etkileri bulunmaktadır. Yaşana- 
bilir bir kent hedefine ulaşabilmek için öncelikle halkın sosyal, ekonomik ve çevresel ihtiyaçlarının karşılanması gerekmektedir. Hızlı büyüyen kentlerde kırsal alandan kente olan göçü sürdürülebilir kılmak için bölgesel ve ulusal düzeylerde kent planlama politikalarına ihtiyaç bulunmaktadır. Bunun için ise planlama aşamalarına halk katılımının sağlanması büyük önem arz etmektedir (Dave, 2010, s.25; Pacione, 2003, s.28). Son kırk yılda gelişmiş ülkelerde yapılan planlama çalışmalarında daha katılımcı yönetişim biçimleri üzerine önemle vurgu yapılmaktadır. Araştırmacilar ve karar vericiler daha kapsayıcı ve katılımcı yaklaşımın kentsel sistemlerin uzun vadeli çevresel sürdürülebilirliğini sağlamada daha başarılı olduğunu vurgulamaktadırlar. Bunun yanında kentsel çevre konularının çok faktörlü bir perspektife sahip olması nedeniyle farklı bilimsel alanlardan uzmanların birlikte çalışmasının önemine vurgu yapılmaktadır (Bonnes vd., 2007, s.75).

Araştırmanın sonucunda elde edilen bulgular Bingöl'ün yaşanabilir bir kent olma yolunda önemli sorunları olduğu göstermektedir. Katılımclar kentsel yaşam kalitesine etki eden sorunlar nedeniyle kenti yetersiz bulmakta ve yapılması gerekenlerle ilgili öncelikler sunmaktadır. Yeşil alan ihtiyacının karşılanması, gençler ve çocuklar için oyun ve spor olanaklarının geliştirilmesi, trafik ve otopark sorunun çözülmesi, çevre kirliliğine neden olan çöp sorununun ortadan kaldırılması diğer alanlara göre daha öncelikli çözülmesi istenilen sorunlar olarak görülmektedir. Bunların dışında kent halkı çarpık kentleşme, kent estetiği, toplu ulaşım sıkıntısı, altyapı sorunları ve temel çevresel sorunların giderilmesi konusunda çözümler üretilmesini beklemektedir. Bu sorunların giderilmesinde en önemli sorumluluk yerel yönetimlere düşmekle beraber tüm kamu kurumlarına, sivil toplum kuruluşlarına ve kentte yaşayan tüm bireylere görev düşmektedir. Kentte sürdürülebilir ve yaşanabilir bir kent olma gündemi oluşturulamazsa sağlıklı bir kentleşmeden bahsetmek mümkün olamayacaktır. Bu bakımdan öncelikle aşağıdaki önerilerin göz önünde bulundurulması yararlı olacaktır.

1. Valilik ve Belediye ortaklığında kentsel gelişim politikaların belirlenmesi, gelişim planlarının ve eylem planlarının oluşturulması,

2. Bu araştırma da belirtilen sorunların çözümü için kısa, orta ve uzun vadeli çalışma takvimi ve faaliyet planının hazırlanması ve yerel kamuoyunun bilgisine sunulması,

3. Mevcut imar planının gözden geçirilmesi ve yasal mevzuata uygun olmayan yapılaşmaya izin verilmemesi, 
4. Mevcut ulaşım sisteminin gözden geçirilmesi, yeni otopark alanlarının oluşturulması, yeni yapılacak olan binalara açık-kapalı otopark zorunluluğu getirilmeli,

5. Kent geneli için sürdürülebilir yeşil alt yapı planlanının hazırlanması ve halkın rekreasyon ihtiyaçlarının karşılanmasına yönelik tedbirlerin alınması,

6. Kentlilik bilincinin artırılmasına yönelik farkındalık faaliyetlerinin yapılması ve kentleşme ile ilgili sosyal projelerin geliştirilmesi.

\section{Teşekkür}

Bu araştırma, "Bingöl Kent Merkezi Açık-Yeşil Alanların Yeterliliği, Kentleşme ile İlgili Temel Sorunlar ve Gelişim Senaryolarının Çoklu Araştırma Yöntemleri Kullanımı ile Belirlenmesi" isimli BAP-ZF.2018.00.011 no'luBÜBAP projesi tarafından desteklenmiştir. Proje kapsamında maddi ve manevi katkılarından dolayı Bingöl Üniversitesine teşekkür ederiz. 


\section{EXTENDED ABSTRACT}

\section{An Evaluation on the Physical Problems and Priorities of Bingöl City on the Path of Being Livable City \\ Hüccet Vural \\ Bingöl University}

The city differs from the rural areas in terms of its administrative structure, social relations, social-cultural structure, opportunities, lifestyles, and population density. The majority of today's world population lives in cities, so the importance of cities is increasing more and more. The fact that the cities are large in terms of population and area necessitates planning within the framework of scientific and technical rules. However, population and spatial growth pose important problems.

The inability to produce solutions to the needs of the growing population in the city creates a variety of problems such as infrastructure problems, housing shortages, unplanned urbanization, lack of green space, reconstruction problems and heavy traffic. The basis of environmental problems arises from the negative effects of human beings on the environment while benefiting from natural resources and ecosystems.

The increase in urban problems has caused the emergence of various concepts. The most used of these concepts are; "Healthy city" and "sustainable urban development". A healthy city can be defined as a city that contains all the necessary elements for a livable city and implements the structural changes needed in this road. The quality of urban life is also important because of its contribution to human health. Because the individual's life quality, satisfaction, and happiness will have a positive impact on the city's quality of life. Sustainable city concept, on the other hand, is considered as a general framework in today's urban planning, while it also focuses on the protection of the natural environment ecologically and handling the planning from a social, environmental and economic perspective.

One of the things to be done in solving urban problems is to ensure the participation of the people in the management. Addressing urban management with a participatory approach; It is accepted that the city will be more 
successful in ensuring its social, cultural, environmental and economic sustainability. Many scientists in this field emphasize that local environmental policies will be supported by a higher consensus among the public and will be sustainable and effective in the long term.

Although there are few studies examining the urban problems of the Bingöl province, no research has been found studying the views, expectations and demands of the public regarding the urbanization process. This research was carried out to determine the opinions, suggestions and demands of the public about urban problems in Bingöl city center. The survey technique, which is known as the most common method of collecting data from primary sources, was used in this the study. It was calculated 383 people as the appropriate sample number by considering with $95 \%$ confidence interval and $5 \%$ margin of error. But, in practice, this number has been exceeded. A total of 598 people, 264 women and 334 men, participated in the survey. It was determined that the survey participants were between 30-45 years of age, high rates of married, and middle-income individuals.

The results of the survey were analyzed by using SPSS 22 software. In addition to the descriptive evaluations, it was used for meaningfulness tests according to participant profile and old-new urban texture variables. According to the individuals who participated in the study, the most important problems were green space deficiency and environmental pollutiongarbage problems at the scale of the neighborhood and green space deficiency and parking problem throughout the city. In addition, the priorities of the participants for solutions were lack of green space (17.8\%) firstly, environmental pollution-waste problem (13.1\%) secondly and traffic problem $(12.4 \%)$ thirdly. In the evaluation of 16 problem areas, it was determined that the results did not change according to the old-new residential areas. Urban people also demand to be solved issues such as distorted urbanization, urban aesthetics, public transportation shortages, infrastructure problems, and basic environmental problems. Local administrations, government, and municipality are primarily responsible for the elimination of these problems. Besides, all public institutions, there is also the task of civil society organizations and citizens. As a result, the research findings indicated that a sustainable and livable city agenda should be established without delay. In this regard, it would be useful to consider the following suggestions first. 
1. Determination of urban development policies, the establishment of development plans and action plans in the partnership of the Governorship and Municipality,

2. Preparation of short, medium and long-term work schedule and action plan for the solution of the problems mentioned in this research and presentation to the local public,

3. Reviewing the existing zoning plan and not permitting construction that does not comply with the legal legislation,

4. Review of the current transportation system, creation of new parking areas, and the necessity of open-closed parking lot for new buildings,

5. Preparation of sustainable green infrastructure plans for the city in general and taking measures to meet the recreation needs of the public,

6. Carrying out awareness activities to increase urban consciousness and developing social projects related to urbanization.

\section{Kaynakça / References}

Atıl, A., Gülgün, B., ve Yörük, İ. (2005). Sürdürülebilir kentler ve peyzaj mimarlığı. Ege Üniversitesi Ziraat Fakültesi Dergisi, 42(2), 215-226.

Aytaç, Ö. (2013). Kent mekânları ve kimlik/farklılık sorunu. Ídealkent, 4(9), 138169.

Başaran, I. (2007). Sağlıklı kentler kavramının gelişiminde sağlıklı kentler projesi. Dokuz Eylül Üniversitesi Sosyal Bilimler Enstitüsü Dergisi, 9(3), 207-229.

BulBonnes, M., Uzzell, D., Carrus, G. ve Kelay, T. (2007). Inhabitants' and experts' assessments of environmental quality for urban sustainability. Journal of Social Issues, 63(1), 59-78.

Dave, S. (2010). High urban densities in developing countries: A sustainable solution?. Built environment, 36(1), 9-27.

Doğan, S. Ş., ve Yılmaz, S. (2019). coğrafi bilgi sistemleri ve uzaktan algılama yöntemleri ile arazi örtüsü/alan kullanım değişimlerinin belirlenmesi: Bingöl kent merkezi örneği. Türk Tarm ve Doğa Bilimleri Dergisi, 6(3), 536-545.

Drakakis-Smith, D. (1995). Third world cities: sustainable urban development, 1. Urban studies, 32(4-5), 659-677.

Esen, F. (2019). Coğrafi Bilgi Sistemleri (CBS) ve Uzaktan algılama (UA) ile Bingöl Şehri ve çevresindeki yerleşmelerin mekânsal gelişimi için uygun alanların tespit edilmesi. Anemon Muş Alparslan Üniversitesi Sosyal Bilimler Dergisi, 7(2), 101-112. 
Freire, M. (2006). Urban planning: Challenges in developing countries. In International Congress on Human Development, Madrid.

Gözener, B, ve Sayılı, M. (2013). Tüketicilerin açık süt ve süt ürünleri tüketim tercihlerinin incelenmesi Tokat-Turhal İlçesi örneği. Sosyal Bilimler Araştırmaları Dergisi. I, 160-175.

Grimmond, S. U. E. (2007). Urbanization and global environmental change: local effects of urban warming. Geographical Journal, 173(1), 83-88.

Güven, A., ve Alan, Ç. (208). Kentsel ve çevresel sorunların çözümünde yerel yönetimlerin rolü. Uluslararası Su ve Çevre Kongresi SUÇEV (22-24 Mart 2018) Bildiriler Kitabı, Bursa/Türkiye.

Jennings, V., Johnson Gaither, C., ve Gragg, R. S. (2012). Promoting environmental justice through urban green space access: A synopsis. Environmental Justice, 5(1), 1-7.

Jim, C. Y. (2013). Sustainable urban greening strategies for compact cities in developing and developed economies. Urban Ecosystems, 16(4), 741-761.

Kiziroğlu, A. M. (2003). Türkiye'de kentleşme ve kentleşme politikaları. TC Maltepe Üniversitesi İktisadi ve İdari Bilimler Fakültesi Ekonomik, Toplumsal ve Siyasal Analiz Dergisi, 2, 53-77.

Kocalar, A. C. (2018). Akıllı ve ekolojik kentlerle sürdürülebilir kentsel tasarım: "Arazi bilgi yönetimi sistemi (Abys)" "Mülkiyet ve imar hakları aktarımı modeli (Miham)". 26. Kentsel Tasarım ve Uygulamalar Sempozyumu: Kentsel Tasarımda Yeni Uygulamalar, Yaklaşımlar Sempozyum Kitabı, ISBN No: 978-605-68202-1-2 24-25 May1s 2018.

Lopes, M. N., ve Camanho, A. S. (2013). Public green space use and consequences on urban vitality: An assessment of European cities. Social indicators research, 113(3), 751-767.

Oktay, D. (2007), Sürdürülebilirlik, yaşanılabilirlik ve kentsel yaşam kalitesi. Mimarlk Dergisi, 335, 19.

Pacione, M. (2003). Urban environmental quality and human wellbeing-a social geographical perspective. Landscape and urban planning, 65(1-2), 1930 .

Pearsall, H., Pierce, J. (2010). Urban sustainability and environmental justice: evaluating the linkages in public planning/policy discourse. Local Environment, 15(6), 569-580.

Sezik, M. (2019). Türkiye'de yerel yönetimlerin yaşanabilir kent oluşturma politikaları. Kahramanmaraş Sütçü Imam Üniversitesi Sosyal Bilimler Dergisi, 16(2), 703-716. 
Sınmaz, S. (2013). Yeni gelişen planlama yaklaşımları çerçevesinde akıllı yerleşme kavramı ve temel ilkeleri. Megaron, 8(2), 76-86.

Soylu, H. (2009). Bingöl'de hızlı şehirleşmeden kaynaklanan çevre sorunlar1. Atatürk Üniversitesi Sosyal Bilimler Enstitüsü Dergisi, 13(1), 87-104.

Tatlılığlu, K. (2015). Kentleşme ve sürdürülebilir kalkınma sürecinde Bingöl ilinin sosyo-kültürel ve ekonomik durumu üzerine genel bir değerlendirme. Bingöl Araştırmaları Dergisi, 2(1), 29-54.

Toprak, D. (2017). Türkiye'nin Çevre Politikasında Yerel Yönetimlerin Rolü: Yerel Yönetim Bütçesinin İncelenmesi. Maliye Araştırmaları Dergisi, 3(2).

Türkiye İstatistik Kurumu (TÜİK), (2018). Adrese dayalı nüfus kayıt sistemi sonuçları 25.12.2019 tarihinde http://tuik.gov.tr/Start.do adresinden erişilmiştir.

Üstündağ, Ö. (2011). Bingöl şehir merkezinin doğal ortam analizi ve fiziksel planlamasi. Yayınlanmamış Doktora Tezi, Fırat Üniversitesi Sosyal Bilimler Enstitüsü Coğrafya Anabilim Dalı, Elazığ.

Yenice, M. S. (2012). Konya kentinin planlama tarihi ve mekânsal gelişimi. Erciyes Üniversitesi Fen Bilimleri Enstitüsü Fen Bilimleri Dergisi, 28(4), 343-350.

Yüksel, M., Yeşil, M. (2017). Kent ve yaşam: Ordu Kenti örneği. Atatürk Üniversitesi Sosyal Bilimler Enstitüsü Dergisi, 21(2), 679-693.

\section{Kaynakça Bilgisi / Citation Information}

Vural, H. (2020). Bingöl'ün yaşanabilir kent olma yolunda fiziki problemleri ve öncelikleri üzerine bir değerlendirme. OPUSUluslararası Toplum Araştırmaları Dergisi, 15(10. Yıl Özel Sayısı), 5006-5031. DOI: 10.26466/opus.672743 